\title{
The impact of climate smart agriculture on household welfare in smallholder integrated crop-livestock farming systems: evidence from Zimbabwe
}

\author{
Angeline Mujeyi ${ }^{1^{*} \mathbb{D}}$, Maxwell Mudhara ${ }^{1}$ and Munyaradzi Mutenje ${ }^{2}$
}

\begin{abstract}
Background: Agriculture contributes significantly to the welfare of smallholder farmers, but it has become highly susceptible to climate change, due to its reliance on the increasingly erratic rainfall patterns. Climate Smart Agriculture (CSA) offers important opportunities for enhancing food security and incomes through increased agriculture productivity. Technology evaluation through impact studies provides information on the effect of CSA on farmer welfare, thereby highlighting its potential in optimizing agriculture productivity. This paper analyses the impact of CSA adoption on food security and income of households, using cross-sectional survey data collected from 386 households across four districts in Zimbabwe. The analysis was done using the endogenous switching regression model which controls for selection bias and unobserved heterogeneity, a commonly used method in adoption impact analysis.
\end{abstract}

Results: The study found several agricultural and socio-economic factors which affect adoption and food security. The econometric results show that the status of soil fertility in fields, distance to input and output markets, ownership of communication assets, and Total Livestock Units (TLU) have a significant impact on the decision of farmers to adopt CSA. The Average Treatment Effects on the Treated (ATT) and Average Treatment Effects on the Untreated (ATU) were found to be positive and significant for adopters and non-adopters, indicating that CSA adoption has had a significantly positive impact on the welfare of the farmers. An analysis of the outcomes revealed that the characteristics of farmers and farms, as well as market factors, significantly affect the welfare of households. The household income, with reference to the adoption of CSA, was significantly affected by factors such as the education of household head, labour size, TLU, and asset index. Food security was influenced by factors such as the education of household head, $T L U$, access to sanitation, and arable land size.

Conclusions: The study concludes by giving policy recommendations centred on the access to inputs, sanitation, and encouraging investing in assets and TLU. The findings indicate that the adoption of CSA has a positive impact on the welfare of farmers. To exploit the full potential of these technologies, the study suggests that access to timely weather forecasts must be ensured, that sanitation must be promoted, and that incentives must be provided for agricultural input agro-dealers to decentralize to rural areas.

Keywords: Household income, Food security, Endogenous switching regression, Zimbabwe

\footnotetext{
*Correspondence: munogona@gmail.com

${ }^{1}$ College of Agricultural, Engineering and Science, Discipline

of Agricultural Economics, University of KwaZulu-Natal, Private Bag X01, Scottsville 3209, Pietermaritzburg, South Africa

Full list of author information is available at the end of the article
}

\section{Background}

The agricultural sector plays an important role in the economic growth and development of Zimbabwe, as evidenced by its $15-18 \%$ share of the Gross Domestic

c) The Author(s) 2021. This article is licensed under a Creative Commons Attribution 4.0 International License, which permits use, sharing, adaptation, distribution and reproduction in any medium or format, as long as you give appropriate credit to the original author(s) and the source, provide a link to the Creative Commons licence, and indicate if changes were made. The images or other third party material in this article are included in the article's Creative Commons licence, unless indicated otherwise in a credit line to the material. If material is not included in the article's Creative Commons licence and your intended use is not permitted by statutory regulation or exceeds the permitted use, you will need to obtain permission directly from the copyright holder. To view a copy of this licence, visit http://creativeco mmons.org/licenses/by/4.0/. The Creative Commons Public Domain Dedication waiver (http://creativecommons.org/publicdomain/ zero/1.0/) applies to the data made available in this article, unless otherwise stated in a credit line to the data. 
Product (GDP), its national export earnings (40\%), its raw material provision to the agro-industry $(60 \%)$, and its employment generation $(50 \%)[1,2]$. The country has key agricultural resources in the form of rich fertile land, which is ideal for producing high-value crops such as horticulture, field cash crops such as tobacco and cotton, as well as field food crops such as maize, groundnuts, and cowpeas, among others, and the country was previously dubbed as the 'bread basket' of Africa. However, this status changed following the land reform of 2000 , which was followed by a subsequent decrease in investments, along with other destabilizing macro-economic factors, such as hyperinflation and the unreliable supply of electricity and fuel. The country is now a net importer of food commodities annually [3]. Zimbabwe's smallholder farmers, who constitute about $70 \%$ of the population, own approximately $55 \%$ of the total cultivated land and rely on rain-fed agriculture for their livelihoods [3]. Agricultural productivity has remained low, averaging less than 1 tonne/ha over the past 10 years for the staple crop maize (Zea Mays) and low livestock off-take rates of less than $10 \%[4,5]$. Livestock productivity is constrained by the low quality and unreliable availability of forage during the dry season, while crop productivity is constrained by infertile sandy soils and the low use of technologies (i.e., improved varieties, fertilizers, etc.). In addition, farmers face under-developed markets that limit their financial returns, because they are characterised by high input costs and low output prices, coupled with droughts, as a result of climate change [6-8]. Climate change has led to a shorter growing season, higher temperatures, frequent and severe droughts, as well as pest outbreaks, e.g., the Army Worm and Tuta [9], which have resulted in reduced crop yields. Studies have found that crop yields have been reduced as a result of warming and the results of modelling studies further showed that the trend will continue and will be compounded by rising atmospheric $\mathrm{CO} 2$ concentrations leading to a in food and forage quality. Livelihoods and food security will be at risk from volatile price and yields caused by extreme weather conditions [10, 11]. Models predict that Sub-Saharan Africa warming will be greater than the global average leading to extreme events such as droughts and floods, thereby negatively affecting smallholder farmers who heavily depend on rain-fed agriculture for livelihoods [12]. High incidence of pests and diseases has also been reported which negatively affected livestock and crop productivity [12]. Progressive decline of yields over consecutive agriculture seasons will negatively affect food security for households who usually rely on own production for staple crops [13]. The volatile rainfall patterns pose a serious threat to farmers, as water is a necessary resource that becomes constrained under such circumstances. Thus, the Government of Zimbabwe [2, 14], in collaboration with research and development organisations, has promoted Climate Smart Agriculture (CSA). CSA refers to agricultural practices that sustainably increase productivity and resilience (adaptation) and reduce or remove greenhouse gases (mitigation) [6,15].

\section{Significance of CSA in crop-livestock smallholder farming systems}

The adoption of CSA is one important route towards improving the welfare of smallholder farming communities in developing countries experiencing a changing climate and reduced land for agricultural expansion [1618]. CSA can help farmers to meet the growing demand for food. Generally, CSA contributes to food security, economic development, and poverty reduction (13). Literature suggests that increased agriculture productivity can improve the welfare of households by increasing their income and improving their food security, by producing their own food $[9,19]$. Research and development organisations, in collaboration with government departments, have spear-headed the adoption of various CSA technologies in Zimbabwe [14]. Productivity and welfare gains from CSA crop and livestock technologies have the empirical support of on-station and on-farm trials. For example, on-farm trials on CA systems that were run by researchers from CIMMYT [20] from 2012-2015 in Zambia found that dibble stick, rip-line, and direct seeding CA systems had a $6-18 \%, 12-28 \%$, and $8-9 \%$ greater maize yield, respectively, compared to the conventional tillage system. The study also found that the rotation of maize with legumes (cowpeas and soybeans) significantly increased the maize yields and net returns (as high as US $\$ 312$ to $\$ 767$ ha -1 , compared to only US $\$ 64$ to $\$ 516$ under conventional practices). Another study by [21] found that the adoption of drought-tolerant maize varieties increased maize yields among the adopters by $13.3 \%$ and reduced the down-side risk exposure by $81 \%$.

Soil and water management CSA practices protect the soil (minimum tillage), reduce water losses from runoff and improve water infiltration (mulching), and reduce evaporation and improve soil fertility (intercropping, rotation, and manure use) [22, 23]. These are complemented by CSA crop practices, such as the use of improved crop varieties (drought-tolerant maize, orange maize, and improved legumes). Several studies have assessed the impact of CSA, and found both direct results (improved crop and livestock productivity, and reduced total variable costs) and indirect results (improved food security through the increased availability of staple crops at household level and in markets, per capita consumption, increased household income (19) [24], and increased demand for farm labour, which brings about better wage 
returns for agricultural labour) [24-29]. Researchers in Kenya used the endogenous switching regression (ESR) to investigate the impact of CSA packages on food security (using Household Food Consumption Score (HFCS) and Household Dietary Diversity as proxies for food security). Other researchers have also used composite indexes which use normalisation and weighting methods such as the Food Insecurity Multidimensional Index which synthesizes the four dimensions of food security, i.e., availability, access, utilisation, and stability [30]. The study found that farmers who used larger CSA packages comprising of crop management, field management, risk reduction practices, and specific soil management practices were $56.83 \%$ and $25.44 \%$ more food secure in terms Household Food Consumption Score and Household Dietary Diversity Scores, respectively, compared to their non-adopter counterparts [11]. A study by [28] found that adoption of CSA such as multiple stress-tolerant crops improved household income by $83 \%$. This in turn improved household asset accumulation.

The International Maize and Wheat Improvement Centre (CIMMYT), in collaboration with government departments and the private sector, has promoted highyielding and disease- and drought-tolerant maize, orange maize, and early maturing, protein-quality maize [31, 32]. One research study found that the adoption of droughttolerant maize (DTM) by smallholder farmers in Zimbabwe significantly enhanced maize productivity and, consequently, the quantities that could be set aside for sale and personal household consumption [9]. Various donor-funded relief and recovery programs have promoted Conservation Agriculture (CA) since 2004. It has been noted that CA can increase the yields of smallholder farmers through soil fertility improvement, soil and water conservation, and organic carbon sequestration [33]. Studies in Malawi and Zambia have shown a high yield advantage of over 1 tonne per hectare [20,34]. Livestock productivity has been enhanced through supplementary feeding with forage legumes, such as the velvet bean (Mucuna pruriens), cowpea (Vigna unguiculata (L.), lablab (lablab purpureus), and browse legumes, such as the acacia (Senegalia and Vachellia), and the Calliandra and Leucaena trees [26, 35], which are promoted by the International Livestock Research Institute (ILRI) and World Agroforestry Centre (ICRAF), in collaboration with Nongovernmental Organisations (NGOs) and government departments. Researchers have reported increased benefit cost ratios of 1.12-3.03 in Zimbabwe [36].

The CSA technologies are therefore very relevant for countries like Zimbabwe, which are considered to be climate change 'hotspots' because of the increased probability of extreme events, such as droughts [37]. Much evidence has been generated on the impact of CSA in
Zimbabwe, mainly from on-farm and on-station experiments; however, there is a paucity of rigorous evidence under actual non-researcher-managed smallholder farming conditions across different agro-ecological zones in Zimbabwe. Evidence from long-term regional trials in Zimbabwe, Zambia, Malawi, and Mozambique found that CA maintained higher infiltration rates $(55-221 \%$ higher than conventional) and conserved soil moisture (14\% or above moisture benefits in CA plots over conventional plots) resultantly leading to increased productivity (a12- 16\% (or 592-847 $\mathrm{kg} \mathrm{ha}^{-1}$ ) maize yield benefit in a normal year and 38\% and 66\% (or 1314-2815 $\mathrm{kg} \mathrm{ha}^{-1}$ ) yield benefits in a dry year) [38] and profitability. The yield benefits were, however, noticeable over a lag period of 2-5 cropping seasons. There has also been a paucity of insight in peer-reviewed publications, compared to that for other southern African and East African countries like South Africa and Uganda, mainly due to lack of data for Zimbabwe. This study thus bridges the gap and uses quantitative evidence from a cross-sectional dataset. Several studies have measured the impact using a single economic model, such as Propensity Score Matching (PSM) $[39,40]$, which is ideal when differences in adopters and non-adopters are captured through only observable characteristics. The results from PSM can, however, be biased, especially when there are unobservable characteristics such as motivation, a farmer's management ability, farmer-to-farmer networking, informal associations, or the transaction costs experienced by the farmers as a result of poor infrastructure. To counter these challenges, this study employs the Endogenous Switching Regression (ESR) model [27, 41-44] to measure the impact of CSA adoption on the welfare of farmers, using household income and food security.

Thus, the objective of this paper was to assess the welfare implications of crop and livestock CSA packages in smallholder farming systems. It sought to recommend the characteristics or factors that should be incorporated into the agricultural policies to improve household welfare through the adoption of CSA practices. The rest of the paper is structured as follows: the next section will discuss the methodology (study sampling and study area) of the study, followed by the specifications of the empirical Endogenous Switching Regression model. The methodology section is followed by the presentation and discussion of the study results, and the final section will show the conclusions and recommendations.

\section{Methodology}

\section{Sampling design}

The selection of smallholder households for sampling began with the identification of the four districts in which CSA technologies have been promoted by the 
government and NGOs. The multi-stage random sampling technique was used to select the representative size of 386 farming households. In the first stage, two wards were randomly selected from each district, giving a total of eight wards. Second, one village from each ward was selected. Households were then randomly selected from the sampling frame, namely, the village head's list of all the farming households. A structured household survey questionnaire was administered by the researcher to the smallholder farmers in their homes, and key informant interviews were administered to government extension officers in their wards. The structured questionnaire collected information on (i) general information (date, district, wards, and characteristics of respondent), (ii) household characterisation information (household head sex, age, education level, farming experience, etc), (iii) access to services such as extension, markets, social capital, and asset ownership, (iv) access to credit and determined the household savings, incomes, and expenditure (v) land ownership and crop production (inputs used, their costs, and harvested amounts), (vi) access and use of various crop and livestock CSA technologies and household food security situation. Sample households were distributed within the wards according to the ward sizes (i.e., proportionate sampling). Eventually, the 386 households were randomly selected from the lists provided by the village heads, and the interviews were conducted in March 2018.

From the sampled households, only $33 \%$ were female headed households and the majority $(68 \%)$ were maleheaded household (Table 1). The statistics of reveal that the mean age of the household heads was 50 years. The mean household size was 5 which is slightly higher than the national average household size of 4.2 . Overall, $91 \%$ of the interviewed households relied on farming as a major economic activity which is higher than the estimated 67 to $70 \% \%$ nationally of people who rely on agriculture for their livelihoods. Table 1 gives the summary of the household demographics of the sampled households.

\section{Study area}

The study was conducted in four districts (Goromonzi, Murehwa, Mutoko, and Uzumba-Maramba-Pfungwe) of the Mashonaland East province in Zimbabwe (Fig. 1). The districts were selected based on the variations in the agro-ecological conditions and on the fact that they had been exposed to CSA technologies by the government, in collaboration with non-governmental and research organisations. The agro-ecology of the sites varies in terms of their mean annual rainfall and dominant soil types. Goromonzi and Murehwa are located in agro-ecological regions IIa and IIb, which receive a reliable high rainfall of 750 to $1000 \mathrm{~mm}$ per year, respectively. Mutoko and Uzumba-Maramba-Pfungwe lie in agro-ecological regions III and IV, which receive an erratic low annual rainfall of 500-800 mm, respectively, and are characterised by seasonal mid-season dry spells. Crop-livestock integration is the common farming system in all the sites.

\section{Specification of the empirical model}

Empirical evidence from earlier adoption studies on agricultural technologies guided the choice of variables adopted in the model. These drivers of CSA technologies adoption include household characteristics (age, gender, education and experience of household head, household size, and family labour), asset ownership, institution and technical factors (membership to farmer organisations or group, access to extension, access to credit, trainings on CSA, and ownership to information related assets such as radio, TV, and mobile phones), perceived benefits (e.g., productivity enhancement,, reduced cash inputs, increased incomes, improved food security, reduced risk of crop and livestock losses), economic factors (household income, off-farm income, tropical livestock unit, size, or arable land), market factors (distance input and produce markets), and farm characteristics (soil fertility, slope, and tenure) [13, 45-47].

To increase the willingness of farmers to adopt CSA and thus to make a contribution to the household welfare improvement efforts, it is necessary to be aware of the drivers and obstacles that influence the farmers' decisions and choices and to understand factors that influence the welfare variables, i.e., food security and household incomes. Farm households are assumed to be heterogeneous agents, and their decisions to adopt new technologies are constrained by their resources, information, and

Table 1 Sample characteristics

\begin{tabular}{lccccc}
\hline Characteristic & Goromonzi & Murehwa & Mutoko & U.M.P & Whole sample \\
\hline Age of household head (years) & 51 & 48 & 46 & 53 & 50 \\
Education of household head (years) & 9 & 8 & 10 & 5 & 9 \\
Household size (number) & 5 & 5 & 70 & 6 & 74 \\
Male headed households (\%) & 60 & 99 & 100 & 91 & 68 \\
Farming as main economic activity & 82 & 91 & 91 \\
\hline
\end{tabular}




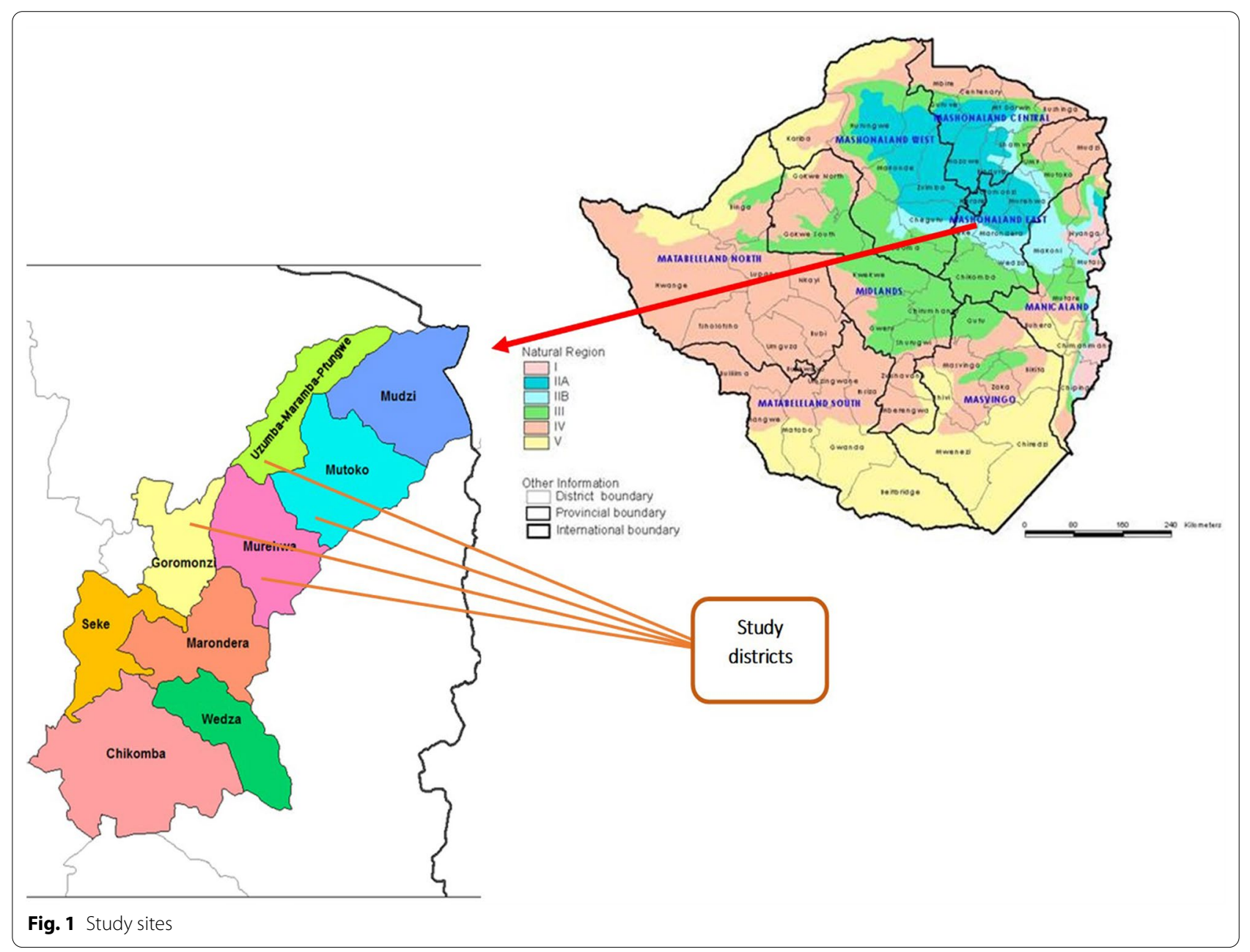

the availability of the technology [48]. Investment in new technologies is attractive to households if the perceived benefits significantly offset the costs. Therefore, the decision to adopt CSA can be viewed through the lens of constrained optimization, where the household chooses the technology if it is available, affordable, and its use is expected to be beneficial. The expected benefits are determined by observable and non-observable factors. Any household that adopts at least one CSA was therefore classified as an adopter. This is so because farmers are assumed to be rational and, as such, they adopt technologies to suit their objectives and to address the constraints that they encounter during production.

To evaluate the impact of CSA technologies on the welfare of selected households, two indices were used, i.e., the average household income and food security. Welfare refers to the total utility derived from all the goods and services consumed. Researchers have used various outcome indicators to measure welfare, including consumption, expenditure, income, asset-based wealth indices, poverty (the poverty gap and poverty head count), and food security, [25, 49-51]. The Food and Agriculture Organisation of the United Nations (FAO) defines household food security as when all the household members have physical and economic access to sufficient, nutritious, and safe food at all times, to meet their dietary needs for an active and healthy life [24]. Several indicators have been used as proxies of household food security to capture the four major dimensions (access, availability, utilisation, and stability), including the Dietary Diversity Score, food insecurity scores, hunger scale, food utilisation (anthropometry as a proxy, i.e., height-for-age, weight-for-height, body mass index (BMI) for age, and weight for age [52-54]) The Household Dietary Diversity Score (HDDS) was used as an indicator of food security. The HDDS measures the number of food groups that are consumed per given reference period. In this study, the HDDS was generated using eight food groups (staples, vegetables, fruits, pulses, meat and fish, oils and fats, milk and its products, and other condiments) from a 24-h 
dietary recall. The DDS therefore ranged from 0 to 8 , with the higher scores correlating with a better nutrient intake.

The adoption of CSA practices can increase crop and livestock production, and thus, more food is available for the household, and the surplus can be sold to generate more income. Some CSA technologies are labour-saving and, as such, they help to avail labour for other off-farm activities that can generate an income for the household. (35). In this case, the food consumed in the previous 7 days was considered. The household income was a combination of on-farm (crop and livestock) and off-farm incomes, as well as other income sources (in-kind transfers, gifts, and remittances).

In previous studies, adoption has been measured as a binary treatment (the Probit and Logit models) or as a continuous treatment (the Tobit and Propensity score methods) according to impact evaluation literature [18, $27,55,56]$. For this study, the ESR was used to evaluate the relationship between the outcome variables (household income and food security) and the exogenous variables. The study used the switching of selection bias, which arises from the fact that treated individuals may differ from those who are non-treated, for reasons other than treatment status. The Switching Regression model is a variant of the classical Heckman Selection model. The ESR has two equations that are simultaneously estimated in STATA using the selection and outcome equations.

\section{Selection equation}

Farmers are faced with two choices, namely, to adopt or not to adopt CSA. This equation (the Probit model) determines the relationship between adoption and the possible determinants:

$$
\mathrm{A}_{\mathrm{i}}^{*}=\beta \mathrm{Z}_{\mathrm{i}}+\mathrm{u}_{\mathrm{i}},
$$

$A=1$ if $A_{i}^{*}>0 A=0$ if otherwise, i.e., $A_{i}^{*} \leq 0$.

$A_{i}^{*}$ is the latent dichotomous (binary) dependent variable for the adoption of CSA.

$\beta$ is a vector of the unknown parameters.

$Z i$ is a vector of the observable characteristics (farmer, farm, etc.) influencing the decision to adopt CSA.

$u_{i}$ is the error term that captures the unobservable characteristics.

\section{Outcome equation}

$$
\begin{aligned}
& \text { Regime } 2 \text { (CSA Non Adopters) : } Y_{2 i} \\
& =X_{2 i} B_{2}+\varepsilon_{2 i} \quad \text { if } A_{1}=0,
\end{aligned}
$$

where $Y_{1}$ and $Y_{2}$ are outcome levels (Food security (HDDS) or gross household income) for adopters and non-adopters, respectively, and $X_{1}$ and $X_{2}$ are the vectors of factors that affect food security that are to be estimated. in Eqs. 1, 2, and 3 are assumed to have a triumvirate normal distribution, with a zero mean and covariance matrix:

$$
\operatorname{Cov}(\mathrm{e} 1 \mathrm{i}, \mathrm{e} 2 \mathrm{i}, \mathrm{ui})=\left(\begin{array}{ccc}
\sigma_{\mathrm{e} 2}^{2} & \cdot & \sigma_{\mathrm{e} 2 \mathrm{u}} \\
\cdot & \sigma_{\mathrm{e} 1}^{1} & \sigma_{\mathrm{e} 1 \mathrm{u}} \\
\cdot & \cdot & \sigma_{\mathrm{u}}^{2}
\end{array}\right),
$$

where $\sigma_{u}^{2}=$ variance of the error term in the selection equation.

$\sigma_{\mathrm{e} 1}^{2}$ and $\sigma_{\mathrm{e} 2}^{2}=$ variance of the error terms in the outcome equation.

$\sigma_{\mathrm{e} 1 \mathrm{u}}$ and $\sigma_{\mathrm{e} 2 \mathrm{u}}=$ covariance of $u_{\mathrm{i}}, e_{1 \mathrm{i}}$ and $e_{2 \mathrm{i}}$.

The ESR model is thus used to compare the expected outcome (food security and income) of the household that adopted CSA (Eq. 4) with respect to the households that did not (Eq. 5) and to investigate the expected food security and incomes in the counterfactual cases (Eq. 6) that the CSA adopters did not adopt and that the CSA non-adopters did adopt (Eq. 7). There is a high likelihood that some unobserved factors that affect the adoption of CSA could also affect the food security or household income (outcome variables). Hence, the error term in the selection equation (Eq. 1) and the error terms in the outcome (Eqs. 2 and 3) may be correlated. To solve this problem, Eqs. 1, 2, and 3 were estimated simultaneously.

The discussed framework is therefore used to estimate the average treatment effect on the treated and the untreated, i.e., the ATT and ATU, respectively. The equations are given as follows:

For CSA adopters with adoption :

$$
E\left(Y_{i 1} \mid A=1, x=X_{i 1} \beta_{1}+\sigma_{1 \varepsilon} \lambda_{i 1}\right. \text {. }
$$

For CSA non - adopters without adoption

$$
E\left(Y_{i 2} \mid A=0, x=X_{i 2} \beta_{2}+\sigma_{2 \varepsilon} \lambda_{i 2} .\right.
$$

For counterfactuals:
Regime 1 (CSA Adopters) : $Y_{1 i}=X_{1 i} B_{1}+\varepsilon_{1 i} \quad$ if $A_{1}=1$ 
i. CSA adopters, had they not adopted : $E\left(Y_{i 2} \mid A=1, x=X_{i 1} \beta_{2}+\sigma_{2 \varepsilon} \lambda_{i 1}\right.$

ii. CSA non-adopters, had they decided to adopt : $E\left(Y_{i 1} \mid A=0, x=X_{i 2} \beta_{1}+\sigma_{1 \varepsilon} \lambda_{i 2}\right.$.

Equations 4 and 5 give the actual expectations, as observed from data, while Eqs. 6 and 7 give the expected outcomes on the counterfactuals. The Average Treatment Effect (ATT) gives a measure of change in the food security outcome (food security or household income):

$$
\begin{aligned}
A T T & =E\left(Y_{i 1} \mid A=1, x\right)-E\left(Y_{i 2} \mid A=1, x\right) \\
& =X_{i 1}\left(\beta_{1}-\beta_{2}\right)+\lambda_{i 1}\left(\sigma_{1 \varepsilon}-\sigma_{2 \varepsilon}\right) .
\end{aligned}
$$

The average treatment effect on the non-adopters:

$$
\begin{aligned}
A T U & =E\left(Y_{i 1} \mid A=0, x\right)-E\left(Y_{i 2} \mid A=0, x\right) \\
& =X_{i 2}\left(\beta_{1}-\beta_{2}\right)+\lambda_{i 2}\left(\sigma_{1 \varepsilon}-\sigma_{2 \varepsilon}\right) .
\end{aligned}
$$

$\lambda_{i 1}$ and $\lambda_{i 2}$ adjust the ATT and ATU, respectively, for the unobserved factors. The ESR model is used to address issues of self-selection and the estimation of treatment effects, when there is a non-random allocation of subjects to treatment and control groups, as is generally the case with observational (as opposed to experimental) data [57].

The important determinants of food security from the literature include education, the age of the household head, input availability, technology adoption, the size of farm, the quality of land, the price of the inputs, gender, the expenditure on food, household size, income levels, access to credit, access to safe water and sanitation, as well as access to markets $[4,42,58]$. The formation of the selection and outcome models was based on the hypotheses that were informed by the literature review. The farmer's decision to adopt or reject CSA is influenced by the simultaneous effect of a number of factors related to the farmer's objectives, constraints, and characteristics, the bio-physical characteristics of the location, asset ownership, and the attributes of the technology [59-61]. It was hypothesized that a farmer's age can either create or reduce confidence in new technology. More experienced farmers can be conservative, thereby avoiding new technologies. On the other hand, experienced farmers can also be willing to try new technologies if they have done it once and obtained positive results. This variable could thus have a positive or negative effect on a farmer's decision to adopt CSA technology. A larger labour size is expected to increase the probability of adopting CSA, as the household can provide timely labour that might be associated with new technologies. Education increases a farmer's ability to obtain, process, and use information, and thus increases the probability that a farmer will adopt CSA. Farm size is expected to be positively associated with the decision to adopt CSA, as farmers with smaller farms are less likely to risk experimenting with new technologies. Access to credit can increase the probability of the adoption of CSA, particularly if new investments are needed for these technologies. Studies by researchers in Ethiopia [62,63] found that access to credit, as well as access to extension and information, were the major drivers of adaptation by farmers. It can be noted that adaptation increases food productivity and that the farm households that did not adapt would benefit the most from adaptation. Researchers in Zimbabwe [47] studied multiple CSA technology adoption determinants in smallholder farming systems, and found that the gender of the household head, institutional factors (market access, information access, and access to credit), and farm characteristics (soil type and labour size) significantly affected adoption. Another study in South Africa by [46] found that adoption was significantly affected by educational status, farming experience, farm income, membership of an agricultural association or group, farmland size, contact with agricultural extension, and exposure to media. The researchers also found statistically significantly negative effects of the distance from the farm to the homestead and off-farm income. Another study in Pakistan [64] found that the adoption of CSA in rice farming systems was significantly affected by education, farming experience, soil quality, farm machinery ownership, access to market information, and contact with extension agents. Other researchers who analysed the factors affecting the adoption of Sustainable Land Management and Climate Smart Agricultural (SLM-CSA) practices in the Amhara region of Ethiopia found that the household characteristics (e.g., sex and household size), the physical characteristics of the farm (slope of field, tenure), access to credit, and access to extension played a crucial role in decisions to adopt adaptation strategies [65]. Higher Livestock Ownership, as measured by Total Livestock Units (TLU), is expected to increase the chances of the adoption of CSA. The availability of off-farm income enables farmers to purchase inputs and it is expected to have a positive influence on adoption. Contact with extension practitioners is hypothesized to increase a farmer's likelihood of adopting CSA, as they offer a major source of information for farmers regarding production.

Researchers are now using the most advanced and recent econometric methods that are based on counterfactual analysis [27]. Taking the observed characteristics of the adopters and non-adopters of CSA, the 
analysis will determine what the outcome variable (the household crop and livestock income and food security situation) would be if adopters had observed nonadopters' characteristics and resources (land, livestock, education, age, family size, land quality, access and the use of agriculture services, etc.), and vice versa. The Household Dietary Diversity Score (HDDS) was used as a proxy for food security. Dietary diversity is a measure of the variety of foods across and within the food groups that are capable of ensuring an adequate intake of essential nutrients to promote good health, as well as physical and mental development [66]. A balanced diet consists of various nutrients that come from multiple food sources and, as such, the more food groups included in the daily diet, the greater the probability of meeting the nutrient requirements. Therefore, a diet that is sufficiently diverse may reflect nutrient adequacy. The dietary diversity scores were created by summing the number of food groups consumed over a reference period.

\section{Empirical results and discussion \\ Descriptive summary of the variables used in the estimations}

Table 2 presents the descriptive statistics of the data for the relevant variables included in the estimation of the ESR model. The $t$ test was used to show the difference between CSA adopters and non-adopters with respect to the relevant continuous variables (i.e., household DDS, log income, education, farming experience, household

Table 2 Variables used in the ESR model and summary statistics

\begin{tabular}{|c|c|c|c|c|c|c|c|}
\hline \multirow[t]{2}{*}{ Variable } & \multicolumn{2}{|c|}{ Non-adopter } & \multicolumn{2}{|c|}{ Adopter } & \multicolumn{2}{|c|}{ Whole sample } & \multirow{2}{*}{$\begin{array}{l}\text { Test Statistic } t / \\
\text { Chi-square value }\end{array}$} \\
\hline & Mean & Std. Dev. & Mean & Std. Dev. & Mean & Std. Dev. & \\
\hline HH food security (DDS) & 6.46 & 2.3 & 6.67 & 1.42 & 6.66 & 1.48 & -0.65 \\
\hline Annual HH income (US\$) & 428.23 & 418.62 & 865.96 & 1618.31 & 841.01 & 1577.71 & 1.62 \\
\hline HH education (years) & 8.77 & 4.19 & 8.25 & 3.73 & 8.28 & 3.75 & 0.63 \\
\hline HH age (years) & 48.45 & 15.94 & 49.95 & 16.49 & 49.86 & 16.44 & -0.41 \\
\hline HH farm experience (years) & 16.23 & 14.06 & 19.06 & 13.79 & 18.9 & 13.8 & -0.94 \\
\hline Household size (number) & 4.5 & 1.97 & 4.96 & 2.48 & 4.93 & 2.45 & -0.85 \\
\hline HH labour size (number) & 3.27 & 1.52 & 3.53 & 2.18 & 3.51 & 2.14 & -0.54 \\
\hline Arable land size (acres) & 2.4 & 1.94 & 3.1 & 2.22 & 3.06 & 2.21 & -1.45 \\
\hline Soil fertility ( $1=$ fertile $0=$ otherwise) & 0.05 & 0.21 & 0.15 & 0.36 & 0.14 & 0.35 & 1.80 \\
\hline Maize area (acres) & 0.99 & 0.47 & 1.36 & 1.04 & 1.35 & 1.02 & $3.34^{\mathrm{a}}$ \\
\hline TLU (number) & 0.85 & 1.95 & 2.32 & 3.61 & 2.24 & 3.55 & $-1.89^{\mathrm{a}}$ \\
\hline Draft livestock (number) & 0.18 & 0.59 & 0.46 & 0.99 & 0.44 & 0.97 & -1.28 \\
\hline Distance output market (Km) & 31.15 & 27.9 & 43.96 & 62.61 & 43.23 & 61.22 & -0.95 \\
\hline Distance input market (Km) & 13.22 & 13.64 & 14.07 & 23.47 & 14.02 & 23.01 & -0.17 \\
\hline Traders buying locally (number) & 3.23 & 4.10 & 4.23 & 6.76 & 4.17 & 6.63 & -0.69 \\
\hline Group membership ( 1 =yes) & 0.41 & 0.50 & 0.49 & 0.50 & 0.48 & 0.50 & 0.53 \\
\hline Extension Contact (number) & 5.27 & 4.23 & 6.43 & 6 & 6.36 & 5.92 & -0.89 \\
\hline Distance to extension (Km) & 39.56 & 121.27 & 18.78 & 87.65 & 19.97 & 89.83 & 1.05 \\
\hline Access to weather forecast $(1=$ yes $0=$ no) & 0.41 & 0.5 & 0.66 & 0.47 & 0.65 & 0.48 & $5.67^{b}$ \\
\hline Awareness CSA $(1=$ yes $0=$ no $)$ & 0.64 & 0.49 & 0.63 & 0.48 & 0.63 & 0.48 & 0.00 \\
\hline Owns communication asset $(1=$ yes $0=$ no) & 0.82 & 0.39 & 0.93 & 0.26 & 0.92 & 0.27 & $3.53^{\mathrm{a}}$ \\
\hline Owns transport asset $(1=$ yes $0=$ no $)$ & 0.55 & 0.51 & 0.41 & 0.49 & 0.42 & 0.49 & -1.45 \\
\hline Owns tillage asset $(1=$ yes $0=$ no) & 0.32 & 0.48 & 0.37 & 0.48 & 0.37 & 0.48 & 0.25 \\
\hline Asset index & 7.36 & 3.82 & 7.92 & 3.57 & 7.89 & 3.58 & -0.71 \\
\hline Credit access $(1=$ yes $0=$ no $)$ & 0.18 & 0.39 & 0.19 & 0.39 & 0.19 & 0.39 & 0.01 \\
\hline Crop income US\$ & 114.77 & 33.32 & 328.11 & 62.98 & 114.77 & 156.32 & -0.83 \\
\hline Livestock income US\$ & 50.46 & 31.50 & 138.02 & 19.71 & 50.45 & 147.73 & -1.09 \\
\hline Off-farm income US\$ & 263 & 361.52 & 399.83 & 726.99 & 392.03 & 711.65 & -0.88 \\
\hline Access to safe water $(1=$ yes $0=$ no $)$ & 0.59 & 0.5 & 0.86 & 0.35 & 0.84 & 0.37 & $11.05^{c}$ \\
\hline Access to sanitation $(1=$ yes $0=$ no $)$ & 0.73 & 0.46 & 0.90 & 0.31 & 0.89 & 0.32 & $5.82^{b}$ \\
\hline
\end{tabular}

HH means Household Head

a, b, c A significance level of $10 \%, 5 \%$, and $1 \%$, respectively 
size, labour size, maize area, TLU, distance to input and output markets, number of local buyers, frequency of extension contact, distance to extension, etc.), while the Chi-square test was used to describe the difference between the two groups with respect to the categorical binary variables (i.e., awareness of CSA, asset ownership, access to credit, access to safe water and sanitation, soil fertility status, access to weather, and group membership). Soil fertility was derived from the main soil type on the farm, as identified by the household head and verified by the enumerator during the survey. Red and black clay soils were classified as fertile, while sand, sandy loam, and loam were classified as infertile, because of their inherent deficiencies in $\mathrm{N}$ and $\mathrm{P}$, as well as their low nutrient retention, low organic matter, and low water-holding capacity $[67,68]$.

Table 2 shows the differences between the adopters and non-adopters of CSA, as given by the summary statistics of the farm households that were surveyed. The results reveal a few significant variables, namely, that there is a significant difference between adopters and non-adopters in terms of access to sanitation and water, the livestock income share, the ownership of communication assets, access to weather forecasts, area under the staple maize crop, and Total Livestock Units. Non-CSA adopters have 0.99 acres under maize, while their CSA counterparts have 1.36 acres. Overall, on average, the farmers grow 1.35 acres of maize ( 0.55 hectares) which is lower than the national average of 0.74 ha [69]. Farmers who adopted CSA have higher herd sizes, they own ICT gadgets, such as radios, phones, and televisions, and they have good access to weather forecast information, safe water, and proper sanitation. These results on ICT and information on ownership of relevant devices point towards the knowledge-intensive nature of CSA technologies in the earlier years. The average age of the household head for the whole sample was 49.86 years which is almost similar to the mean age of the head of household of 50 nationally for communal farmers [69]. The average farm experience of the household heads was about 18.90 years. The average size of the labour force for the total sample was about four members. The average distance to inputs ad output markets was $14 \mathrm{~km}$ and $43 \mathrm{~km}$, respectively. This resonates with assessment findings in 2019 where nationally more than $76 \%$ of households travelled more than $10 \mathrm{~km}$ to access inputs and to sell agriculture produce [70].

\section{Results of the switching regression analysis}

The results of the first stage, i.e., the selection equation (CSA adoption), revealed that factors such as the soil fertility status of the fields, distance to inputs and output markets, TLU, and ownership of communication assets significantly predicted the adoption of CSA in integrated crop-livestock farming systems (Tables 2, 3). A unit increase in distance to the output market increases the odds of the adoption of CSA by 0,004, and a unit increase in TLU increases the probability of CSA adoption by 0.25 . Livestock is a store of wealth in smallholder farming communities and, in addition, households who own them are usually less constrained financially. They can sell livestock to generate income necessary to purchase farm inputs needed for new technologies. An increase in distance to input markets will decrease the odds of adoption by 0.007 . This concurs with other researchers, who found a significant negative association between market (inputs) distance and adoption [47, 71]. This is so because longer distances are associated with high transaction costs, due to the high transportation costs. Tables 3, 4 report the results of the ESR model.

The second set of outcome equations from the ESR (i.e., food security and household income) analysed the factors that affected the outcome with reference to CSA adoption. The analysis revealed that farmer and farm characteristics, as well as market factors, significantly affected the welfare of the households. The findings in Tables 2, 3 revealed that the education of the household head, the labour size, the size of arable land owned, the TLU, and asset index significantly predicted the household income in the study areas. Unsurprisingly, education had a significant positive effect income. More educated household heads can engage in better yield enhancing CSA which will resultantly lead to more products send to the market. Education enhances the capacity of the farmer to make sound decisions on what enterprises to pursue in light of their potential profitability. A higher labour size also contributes to increased incomes through timely farm operations which increase productivity, and some family members can also engage in other non-farm economic activities thereby enhancing household income. TLU had a positive and significant effect on household income. Livestock are indeed a form of savings in rural areas that can easily be liquidated to bridge income gaps that may arise within a household [28]. Asset ownership also have a positive effect on household income. This calls for the need to encourage farmers to invest in agriculture productive assets.

Food security was affected by factors such as the education of the household head, the TLU, access to safe water, and access to sanitation which concurs with prior expectations. Education and Total Livestock units had a positive impact on food security for adopters. These findings concur with other researcher in literature. A study in Mudzi rural area in Zimbabwe showed that that household dietary diversity was influenced by education of the household 
Table 3 Food security ESR model results

\begin{tabular}{|c|c|c|c|c|c|c|}
\hline \multirow[t]{3}{*}{ Variable } & \multirow{2}{*}{\multicolumn{2}{|c|}{$\begin{array}{l}\text { Selection equation (CSA } \\
\text { adoption) }\end{array}$}} & \multicolumn{4}{|c|}{ Outcome equation (food security) } \\
\hline & & & \multicolumn{2}{|c|}{ Non-adopter } & \multicolumn{2}{|l|}{ Adopter } \\
\hline & Coefficient & Robust Std. Err. & Coefficient & Robust Std. Err. & Coefficient & Robust Std. Err \\
\hline HH education & -0.05 & 0.05 & 0.06 & 0.17 & $0.04^{b}$ & 0.02 \\
\hline Household size & & & 0.18 & 0.41 & 0.01 & 0.03 \\
\hline Arable land size & 0.10 & 0.08 & $0.102^{b}$ & 0.077 & -0.01 & 0.03 \\
\hline Distance output market & $0.003^{b}$ & 0.002 & 0.11 & 0.11 & -4.5 & 0.002 \\
\hline Extension contact & -0.02 & 0.03 & -0.04 & 0.40 & -0.001 & 0.02 \\
\hline LogMaizearea & & & 0.21 & 2.41 & -0.19 & 0.25 \\
\hline Off-farm Income & & & 0.001 & 0.003 & 0.00 & 0.00 \\
\hline TLU & $0.25^{\mathrm{b}}$ & 0.10 & 0.29 & 0.18 & $0.06^{c}$ & 0.02 \\
\hline Access to safe water & & & -0.48 & 1.54 & $-0.43^{b}$ & 0.17 \\
\hline Access to sanitation & & & 0.03 & 1.78 & $0.81^{c}$ & 0.25 \\
\hline Distance extension & -0.01 & 0.001 & & & & \\
\hline Distance input market & $-0.007^{b}$ & 0.004 & & & & \\
\hline $\mathrm{HH}$ age & -0.01 & 0.02 & & & & \\
\hline HH farm experience & 0.02 & 0.01 & & & & \\
\hline Local traders & 0.01 & 0.03 & & & & \\
\hline Group membership & -0.24 & 0.33 & & & & \\
\hline Access to weather forecasts & 0.56 & 0.58 & & & & \\
\hline Draft livestock & -0.28 & 0.22 & & & & \\
\hline HH labour size & -0.02 & 0.05 & & & & \\
\hline Awareness CSA & 0.12 & 0.70 & & & & \\
\hline Communication asset ownership & 0.84 & 0.92 & & & & \\
\hline Transport asset ownership & -0.67 & 0.55 & & & & \\
\hline Tillage implement asset & -0.23 & 0.25 & & & & \\
\hline Fertile soil & $0.75^{\mathrm{a}}$ & 0.43 & & & & \\
\hline Credit access & -0.16 & 0.38 & & & & \\
\hline _cons & 0.91 & 0.68 & 4.17 & 6.58 & $5.75^{c}$ & 0.38 \\
\hline /Ins0 & 0.66 & 1.46 & & & & \\
\hline /Ins1 & $0.31^{c}$ & 0.05 & & & & \\
\hline$/ \mathrm{r} 0$ & -0.57 & 3.38 & & & & \\
\hline$/ \mathrm{r} 1$ & 0.11 & 0.34 & & & & \\
\hline sigma0 & 1.93 & 2.82 & & & & \\
\hline sigma1 & 1.36 & 0.07 & & & & \\
\hline rhoo & -0.52 & 2.48 & & & & \\
\hline rhol & 0.11 & 0.33 & & & & \\
\hline
\end{tabular}

$\overline{a, b, c} A$ significance level of $10 \%, 5 \%$, and $1 \%$, respectively

head and livestock ownership [72]. Another study in South Africa also found a significant positive relationship between education and household food security [4]. Educated household heads can decipher information on new innovations such as CSA, and they quickly adopt yield enhancing components that can ultimately boost food security. Studies from 22 lowincome countries also showed correlation between food insecurity with a low level of education [73]. This finding also corroborate with the findings of [74] who reported that educational attainment by the household head could lead better understanding of new technologies. Education enhances the reasoning capability of an individual and enables them to have better awareness of new technologies. It also enables farmers to read and acquires knowledge on agriculture Information Education and Communication (IEC). 
Table 4 Household Income ESR model results

\begin{tabular}{|c|c|c|c|c|c|c|}
\hline \multirow[t]{3}{*}{ Variable } & \multirow{2}{*}{\multicolumn{2}{|c|}{$\begin{array}{l}\text { Selection equation (CSA } \\
\text { adoption) }\end{array}$}} & \multicolumn{4}{|c|}{ outcome equation (log income) } \\
\hline & & & \multicolumn{2}{|c|}{ Non-adopters } & \multicolumn{2}{|c|}{ Adopters } \\
\hline & Coef. & Robust Std. Err. & Coef. & Robust Std. Err. & Coef. & Robust Std. Err. \\
\hline HH Education & -0.05 & 0.04 & $0.05^{\mathrm{a}}$ & 0.30 & $0.02^{c}$ & 0.01 \\
\hline Labour size & -0.03 & 0.05 & 0.09 & 0.06 & $0.04^{c}$ & 0.01 \\
\hline Arable land size & 0.14 & 0.11 & -0.06 & 0.07 & 0.02 & 0.01 \\
\hline TLU & $0.25^{b}$ & 0.13 & 0.03 & 0.06 & $0.02^{b}$ & 0.01 \\
\hline Log crop income share & & & -0.12 & 0.20 & 0.01 & 0.04 \\
\hline Log livestock income share & & & 0.09 & 0.17 & $-0.09^{b}$ & 0.04 \\
\hline Log non-agriculture income share & & & 0.15 & 0.24 & $0.12^{b}$ & 0.04 \\
\hline Asset index & & & 0.02 & 0.03 & $0.04^{c}$ & 0.01 \\
\hline $\mathrm{HH}$ age & 0.01 & 0.02 & & & & \\
\hline HH farm experience & 0.11 & 0.01 & & & & \\
\hline KM to extension & 0.00 & 0.001 & & & & \\
\hline Distance output market & $0.004^{b}$ & 0.002 & & & & \\
\hline Distance input market & $-0.01^{b}$ & 0.01 & & & & \\
\hline Local traders & 0.02 & 0.01 & & & & \\
\hline Group membership & -0.34 & 0.33 & & & & \\
\hline Extension contact & $-0.05^{b}$ & 0.02 & & & & \\
\hline Access to weather forecasts & 0.35 & 0.31 & & & & \\
\hline Draft animals & -0.31 & 0.25 & & & & \\
\hline Awareness CSA & 0.05 & 0.29 & & & & \\
\hline Communication asset ownership & $0.78^{b}$ & 0.32 & & & & \\
\hline Transport asset ownership & $-0.50^{b}$ & 0.24 & & & & \\
\hline Tillage implements & -0.45 & 0.43 & & & & \\
\hline Fertile soil & $0.99^{b}$ & 035 & & & & \\
\hline Credit access & 0.07 & 0.34 & & & & \\
\hline _cons & 1.65 & 1.17 & 1.01 & 0.98 & $1.81^{\mathrm{c}}$ & 0.14 \\
\hline /Ins0 & -0.77 & 0.39 & & & & \\
\hline /ns1 & -0.78 & 0.07 & & & & \\
\hline$/ \mathrm{rO}$ & -1.08 & 0.69 & & & & \\
\hline$/ \mathrm{r} 1$ & -1.29 & 0.96 & & & & \\
\hline sigma0 & 0.46 & 0.18 & & & & \\
\hline sigma1 & 1.46 & 0.03 & & & & \\
\hline rhoo & -0.79 & 0.26 & & & & \\
\hline rho1 & -0.86 & 0.25 & & & & \\
\hline
\end{tabular}

a, b, c A significance level of $10 \%, 5 \%$, and $1 \%$, respectively

There was positive relation between sanitation and food security. Researchers like [71] while investigating food insecurity in rural households of Ethiopia also reiterated that sanitation contributed significantly to food security through ensuring increased capacity of the body to absorb and use the nutrients in their food. In addition, sanitation prevents human faecal pollution thereby reducing spread of diseases. TLU contribute positively to food security through consumption of the products (milk and meat) and even income generation through sales and the money is used to purchase food during critical times.
Farmers can also hire out draft power services and get cash to purchase household food. The draft power also ensures timeliness in farm operations which lead to good yields and this helps farmers to meet food requirements through own production.

There was a negative significant relationship between food security and access to safe water (protected wells and boreholes). While this finding is surprising as it is contrary to priori expectations that good water access can enhance food security through adequate hygiene practices and consumption of safe drinking water, this 
might be because boreholes and the protected wells in these communities are provided by government and donor agents such as NGOs through social protection support programs and this does not have links directly to food security. In as much as these facilities might be available, issues of access due to distance and whether these sources have adequate water for the households also become very important. This negative relationship calls for activities like promoting rainwater harvesting technologies to allow recharging of underground water, so that the protected wells and boreholes will have enough water.

The estimates of the treatment effects of the adoption of CSA on food security and household income are reported in Table 5. The Average Treatment Effect on the Treated (ATT) measures the difference between the welfare of the adopters and what they would have, if they had not adopted CSA. The Average Treatment Effect on the Untreated (ATU), on the other hand, assesses the difference between the welfare of non-adopters and their counterfactuals. These estimates account for selection bias, unlike the mean differences reported in Table 2.

The ATT shows that food security for the treated is positive (1.49) and statistically significant, and it is also positive and statistically significant for the log household income (0.713). This indicates that adopters would have lost income and become food insecure had they had not adopted CSA. The ATU, however, is -0.53 and statistically significant for the log household income, but it is higher for food security (0.37), although it is not statistically significant. Similarly, the Average Treatment Effect (ATE) outcomes from ESR show that non-adopters would have attained crop income gains had they adopted CSA technologies. These findings reveal that adopters of CSA would have been worse off, in welfare terms, had they not adopted it. Non-adopters would also have benefited, food security-wise, had they adopted CSA. As presented in Table 4, CSA technology adoption significantly affects both the food security and household income of adopters. This finding is in line with the previous studies, which point towards the positive contribution of CSA adoption on household welfare [11, 28, 29]. A study in Teso North Sub-county, Busia County in Kenya found that farmers who adopted CSA were more food secure compared to non-adopters [11]. The study demonstrated a robust relationship between food security and CSA adoption. Therefore, CSA interventions that are aimed at improving food security in smallholder farming communities may have significant welfare gains for smallholder farmers. Generally, Climate Smart Agriculture technologies enhance household welfare through improved agricultural productivity.

\section{Conclusion and implications}

This study examined the impact of CSA on the welfare of households, using the ESR model. Variables relating to the soil fertility status of the fields, access to inputs markets, TLU, and ownership of communication assets have emerged as having a significant impact on a farmer's decision to adopt CSA. The ATT is positive and significant which indicates that CSA adoption has resulted in a significantly positive impact on the welfare of the farmers. Several policy implications can therefore be drawn from these findings. Government should consider providing incentives for agro-dealers to invest in agricultural businesses that sell inputs in rural areas. In as much as taxes are good for government revenue, the government could reduce the taxes for rural agro-dealers, so that inputs are supplied and made available closer to where the farmers live, to provide easier access. The government could also provide incentives for financial service providers, to avail affordable financial products that are targeted at agro-dealers, and to enable them to stock the required inputs in adequate quantities. Alternatively, the incentives can be offered to the manufacturers of inputs, as well as the buyers of agricultural produce, to encourage them to foster flexible and mutually beneficial marketing arrangements with the rural agrodealers. The study findings show that reducing the distance to input markets will go a long way in increasing the probability of CSA technology adoption, which is associated with improved productivity. Enhanced productivity will, in turn, improve the welfare of households by increasing food security and household incomes. In addition, related to the improved and significant impact on food security is the promotion of sanitation. The availability of food alone does not guarantee the food security of households, as it should

Table 5 Average treatment effect of CSA adoption on food security and household income

\begin{tabular}{|c|c|c|c|c|c|c|}
\hline \multirow[t]{2}{*}{ Index } & \multicolumn{3}{|l|}{ Income } & \multicolumn{3}{|c|}{ Food security } \\
\hline & Estimate & Std Err. & $t$ value & Estimate & Std. Err. & $t$ value \\
\hline ATT & 0.713 & 0.016 & $43.72^{c}$ & 1.492 & 0.090 & $16.604^{c}$ \\
\hline ATU & -0.532 & 0.081 & $-6.61^{c}$ & 0.370 & 0.297 & 1.245 \\
\hline ATE & 0.642 & 0.022 & $29.52^{c}$ & 1.428 & 0.087 & $16.349^{c}$ \\
\hline
\end{tabular}

${ }_{a, b, c} A$ significance level of $10 \%, 5 \%$, and $1 \%$, respectively 
be complemented by good sanitation and access to safe water. Development practitioners should target educated farmers because of their greater ability to adopt. Information, Education, and communication (IEC) materials to suit uneducated farmers should be pursued as well to enhance adoption. The study findings have demonstrated that there is a robust relationship between food security and CSA adoption (through the positive and significant ATT). Therefore, interventions that are aimed at improving climate smartness in smallholder farming communities may actually have significant food security and income benefits for smallholder farmers.

\begin{abstract}
Abbreviations
AGRA: Alliance for a green revolution in Africa; ATE: Average treatment effects; ATT: Average treatment effect on the treated; ATU: Average treatment effect on the untreated; BMI: Body mass index; CA: Conservation agriculture; CIMMYT: International maize and wheat improvement centre; CSA: Climate smart agriculture; DTM: Drought tolerant maize; ESR: Endogenous switching regression; GDP: Gross domestic product; GOZ: Government of Zimbabwe; HDDS: Household dietary diversity score; ICRAF: World Agroforestry Centre; ILRI: International Livestock Research Institute; NGOs: Non-governmental organisations; PSM: Propensity score matching; TLU: Total livestock units; UKZN: University of Kwazulu-Natal; ZIMSTAT: The Zimbabwe National Statistics Agency.
\end{abstract}

\section{Acknowledgements}

The authors are grateful to The Ministry of Lands, Agriculture and Rural Resettlement and the Rural District Councils for granting permission for data collection. We also recognize the contribution of the enumerators and ward-based extension officers in data collection. We thank the farmers for providing very useful data and information during the household survey and Focus Group Discussions, without which this study could not have been accomplished. Gratitude also goes to the English editor for going through the revised manuscript. We are very grateful to the valuable remarks and comments from the three anonymous reviewers and the Editor which helped in improving the quality of the paper.

\section{Authors' contributions}

AM analysed and interpreted the household survey data in SPSS and Stata and drafted the paper. MM and MM made substantial contributions in conception and design of the research and commented critically on the draft. They proofread and edited the draft paper. All authors read and approved the final manuscript.

\section{Funding}

The student (Angeline Mujeyi) funded her own research.

\section{Availability of data and materials}

The datasets generated and analysed during the study are not publicly available, due to confidentiality issues, but they are available from the corresponding author on reasonable request and with permission from UKZN.

\section{Ethics approval and consent to participate}

Ethics approval was granted by the UKZN Research Ethics Committee. Respondents signed consent forms before the interviews during data collection.

\section{Consent for publication}

Not applicable.

\section{Competing interests}

No competing interest.

\section{Author details}

${ }^{1}$ College of Agricultural, Engineering and Science, Discipline of Agricultural Economics, University of KwaZulu-Natal, Private Bag X01, Scottsville 3209, Pietermaritzburg, South Africa. ${ }^{2}$ International Maize and Wheat Improvement Centre (CIMMYT), Southern Africa Regional Office, P.O. Box MP 163, Mt Pleasant, Harare, Zimbabwe.

Received: 26 February 2020 Accepted: 26 October 2020

Published online: 09 March 2021

\section{References}

1. ZIMSTAT, "The Zimbabwe 2012 Population Census National Report. Zimbabwe National Statistics Agency (ZimStat)," Harare, Zimbabwe, 2012.

2. GOZ, "Transitional Stabilisation Programme Reforms Agenda :Towards a Prosperous \& Empowered Upper Middle Income Society by 2030." Government of Zimbabwe, Harare, Zimbabwe, 2018.

3. Bonga W. Trade Balance Analysis in Zimbabwe: Import and Export Examination Using Vector Auto-Regression Model. Germany: Munich; 2018.

4. Ngema PZ, Sibanda M, Musemwa L. Household food security status and its determinants in maphumulo local municipality, South Africa. Sustainability. 2018;10:1-23.

5. Enahoro D, et al. Supporting sustainable expansion of livestock production in South Asia and Sub-Saharan Africa: scenario analysis of investment options. Global Food Security. 2019;20:114-21.

6. Ndiritu SW, Kassie M, Shiferaw B. Are there systematic gender differences in the adoption of sustainable agricultural intensification practices? Evidence from Kenya. Food Policy. 2014;49(P1):117-27.

7. Mupangwa W, Thierfelder $C$. Intensification of conservation agriculture systems for increased livestock feed and maize production in Zimbabwe. Int J Agric Sustain. 2014;12(4):425-39.

8. Muoni T, Barnes AP, Öborn I, Watson CA, Shiluli M, Duncan AJ. Farmer perceptions of legumes and their functions in smallholder farming systems in east Africa. Int J Agric Sustain ISSN. 2019;17(3):205-18.

9. Makate C, Wang R, Makate M, Mango N. Crop diversification and livelihoods of smallholder farmers in Zimbabwe: adaptive management for environmental change. SpringerPlus. 2016;5(1):1135.

10. Steenwerth $\mathrm{KL}$, et al. Climate-smart agriculture global research agenda scientific basis for action. Agric Food Secur. 2014;2(11):1-39.

11. Wekesa BM, Ayuya OI, Lagat JK. Effect of climate - smart agricultural practices on household food security in smallholder production systems micro - level evidence from Kenya. Agric Food Secur. 2018;7(80):1-14.

12. Belay A, Recha JW, Woldeamanuel T, Morton JF. Smallholder farmers ' adaptation to climate change and determinants of their adaptation decisions in the Central Rift Valley of Ethiopia. Agric Food Secur. 2017:6:1-13.

13. Ouédraogo M, Houessionon P, Zougmoré RB, Partey ST. Uptake of climate-smart agricultural technologies and practices: actual and potential adoption rates in the climate-smart village site of Mali. Sustainability. 2019;11(17):4710.

14. Mujeyi A. Policy and Institutional Dimensions in Climate-Smart Agriculture Adoption : Case of Rural Communities in Zimbabwe. In: Handbook of Climate Change Resilience, W. Leal Filho (ed.), Ed. Springer Nature Switzerland AG 2018, 2018.

15. Palombi L, Sessa R. Climate smart agriculture Sourcebook. Rome: Food and Agriculture Organization of the United Nations (FAO); 2013.

16. Braimoh AK. Global agriculture needs smart science and policies. Agric Food Secur. 2013;2(6):1-2.

17. Zougmoré $R$, et al. Toward climate-smart agriculture in West Africa: A review of climate change impacts, adaptation strategies and policy developments for the livestock, fishery and crop production sectors. Agric Food Secur. 2016;5(1):1-16.

18. Khatri-chhetri A, Aryal JP, Sapkota TB. Economic benefits of climatesmart agricultural practices to smallholder farmers in the Indo-Gangetic Plains of India Economic benefits of climate-smart agricultural practices to smallholder farmers in the Indo-Gangetic Plains of India. Curr Sci. 2016;110(April):1251-6. 
19. Sani S. Analysis of households food insecurity and its coping mechanisms in Western Ethiopia. Agric Food Econ. 2019;7:5.

20. Mupangwa $W$, et al. Productivity and profitability of manual and mechanized conservation agriculture (CA) systems in Eastern Zambia. Renew Agricu Food Syst. 2017;1:1-7.

21. Wossen T, Abdoulaye T, Alene A, Feleke S, Menkir A, Manyong V. Measuring the impacts of adaptation strategies to drought stress: The case of drought tolerant maize varieties. J Environ Manage. 2017;203:106-13.

22. Bodner G, Nakhforoosh A, Kaul H. Management of crop water under drought : a review. Agron Sustain Dev. 2015;35:401-42.

23. Hallama M. Hidden miners-the roles of cover crops and soil microorganisms in phosphorus cycling through agroecosystems. Plant Soil Int J. 2019:434:7-45.

24. Fentie A, Beyene AD. Climate-smart agricultural practices and welfare of rural smallholders in Ethiopia: Does planting method matter? Land Use Policy. 2019;85:387-96.

25. Khonje M, Manda J, Alene AD, Kassie M. Analysis of Adoption and Impacts of Improved Maize Varieties in Eastern Zambia. World Devel. 2015;66:695 706-696706.

26. Kebebe EG. Household nutrition and income impacts of using dairy technologies in mixed crop-livestock production systems. Australian J Agric Resource Econo. 2017;61:626-44.

27. Teklewold H, Gebrehiwot T, Bezabih M. Climate smart agricultural practices and gender differentiated nutrition outcome: an empirical evidence from Ethiopia. World Dev. 2019;122:38-53.

28. Ogada MJ, Rao EJO, Radeny M, Recha JW, Solomon D. Climate-smart agriculture, household income and asset accumulation among smallholder farmers in the Nyando basin of Kenya. World Development Perspectives. 2019;2020:100203.

29. Mwungu CM et al. The Climate-Smart Agriculture Papers. In: TS Rosenstock Ed The Climate-Smart Agriculture Papers. 2019.

30. Taylor P, Santeramo FG. On the composite indicators for food security: decisions matter! On the composite indicators for food security : decisions matter ! Food Rev Int. 2015;31:37-41.

31. Tesfaye K et al. Potential for Scaling up Climate Smart Agricultural Practices: Examples from Sub-Saharan Africa. Clim Change Manage. 2017: 185-203.

32. Lunduka RW, Mateva KI, Magorokosho C. Impact of adoption of drought-tolerant maize varieties on total maize production in south Eastern Zimbabwe. Clim Develop ISSN. 2019;11(1):35-46.

33. Zheng $C$, et al. The impacts of conservation agriculture on crop yield in China depend on specific practices, crops and cropping regions. Crop J. 2014;2(5):289-96.

34. Thierfelder C, Matemba-Mutasa R, Bunderson WT, Mutenje M, Nyagumbo I, Mupangwa W. Evaluating manual conservation agriculture systems in southern Africa. Agr Ecosyst Environ. 2016;222(February):112-24.

35. Gwiriri LC, et al. The potential of replacing conventional dairy supplements with forage legume-based diets in Zimbabwe's smallholder dairy sector. Afr J Range Forage Sci. 2016;0119:155-63.

36. Franzel S, Carsan S, Lukuyu B, Sinja J, Wambugu C. Fodder trees for improving livestock productivity and smallholder livelihoods in Africa. Environ Sustain. 2014;6:98-103.

37. Rurinda J, Mapfumo P, Van Wijk MT, Mtambanengwe F, Rufino MC. Climate Risk Management Sources of vulnerability to a variable and changing climate among smallholder households in Zimbabwe : a participatory analysis. Clim Risk Manage. 2014;3:65-78.

38. Thierfelder C, Chivenge P, Mupangwa W, Rosenstock TS, Lamanna C, Eyre JX. How climate-smart is conservation agriculture (CA)? - its potential to deliver on adaptation, mitigation and productivity on smallholder farms in southern Africa. Food Secur. 2017:9(3):537-60.

39. Kassie M, Shiferaw B, Muricho G. Agricultural technology, crop income, and poverty alleviation in Uganda. World Dev. 2011;39(10):1784-95.

40. Ahmed MH, Geleta KM, Tazeze A, Andualem E. The impact of improved maize varieties on farm productivity and wellbeing: evidence from the east hararghe zone of Ethiopia. Develop Stud Res. 2017:4(1):9-21.

41. Di Falco S. Adaptation to climate change in Sub-Saharan agriculture: assessing the evidence and rethinking the drivers. European Rev Agric Econ. 2014:41(3):405-30.
42. Ahmed MH, Geleta KM, Tazeze A, Ahmed MH. The Impact of improved maize varieties on farm productivity and wellbeing : evidence from the East Hararghe Zone of Ethiopia The Impact of improved maize varieties on farm productivity and wellbeing. Develop Stud Res. 2017:4(1):9-21.

43. Teklewold H, Kassie M, Shiferaw B, Köhlin G. Cropping system diversi fi cation, conservation tillage and modern seed adoption in Ethiopia : Impacts on household income, agrochemical use and demand for labor. Ecol Econ. 2013;93:85-93.

44. Kassie M, et al. Land Use Policy Push-pull farming system in Kenya : implications for economic and social welfare. Land. 2017;77:186-98.

45. Tran D, Goto D. Impacts of sustainability certification on farm income: evidence from small-scale specialty green tea farmers in Vietnam. Food Policy. 2019;83(June):70-82.

46. Abegunde VO, Sibanda M, Obi A. Determinants of the adoption of climate-smart agricultural practices by small-scale farming households in king cetshwayo district municipality, South Africa. Sustainability. 2019;12:195.

47. Mujeyi A, Mudhara M, Mutenje MJ. Adoption determinants of multiple climate smart agricultural technologies in Zimbabwe : Considerations for scaling-up and out. Afr J Sci Technol Innovat Develop. 2019;12:1-12.

48. Midingoyi SG, Kassie M, Muriithi B, Diiro G, Ekesi S. Do Farmers and the environment benefit from adopting integrated pest management practices? Evidence from Kenya. J Agric Econ. 2019;70(2):452-70.

49. Moratti M, Natali L. Measuring household welfare: short versus long consumption. Florence. 2012

50. Larbi A, Hoeschle-Zeledon I, Zemadim B, Azzarri C. Sustainable intensification of crop-livestock mixed farming systems in the Guinea / Sudan Savanna Zone of West Africa Africa RISING Project Document. no. September. IITA, 2014.

51. Afolami CA, Obayelu AE, Vaughan II. Welfare impact of adoption of improved cassava varieties by rural households in South Western Nigeria". Agricu Food Econ. 2015;3(1):18.

52. Ballard Kepple TJ, AW, Cafiero C. Technical Paper. Rome, FAO. The food insecurity experience scale: Developing a global standard for monitoring hunger worldwide. Technical Paper. Rome, 2013.

53. Hussein FM, Ahmed AY, Muhammed OS. Household food insecurity access scale and dietary diversity score as a proxy indicator of nutritional status among people living with HIV/AIDS, Bahir Dar, Ethiopia, 2017. PLoS ONE. 2018;13(6):1-9.

54. Huluka AT, Wondimagegnhu BA. Determinants of household dietary diversity in the Yayo biosphere reserve of Ethiopia: An empirical analysis using sustainable livelihood framework. Cogent Food Agric. 2019:5(1):1690829.

55. Li E, Le Dang H, Li E, Nuberg I, Bruwer J. Factors influencing the adaptation of farmers in response to climate change : a Factors influencing the adaptation of farmers in response to climate change : a review. Clim Devel. 2019:11:765-74.

56. Danso-abbeam G, Bosiako JA, Ehiakpor DS, Mabe FN. Adoption of improved maize variety among farm households in the northern region of Ghana. Cogent Econo Finance. 2018;109(1):1-14.

57. Lokshin M, Sajaia Z. Maximum likelihood estimation of endogenous switching regression models. Stata J. 2004;4(3):282-9.

58. Abdullah, et al. Factors affecting household food security in rural northern hinterland of Pakistan. J Saudi Soc Agric Sci. 2019;18(2):201-10.

59. Aryal JP, Rahut DB, Maharjan S, Erenstein O. Factors affecting the adoption of multiple climate-smart agricultural practices in the Indo-Gangetic Plains of India. Nat Res Forum. 2018:42:141-58.

60. Aryal JP, Jat M, Sapkota TB, Kassie M, Rahut BD, Maharjan S. Adoption of multiple climate- smart agricultural practices in the Gangetic plains of Bihar, India. Int J Clim Change Strat Manag. 2017;10(3):407-27.

61. Mwungu CM, Mwongera C, Shikuku KM, Acosta M, Läderach P, Determinants of Adoption of Climate-Smart Agriculture Technologies at Farm Plot Level : an assessment from Southern Tanzania. In: Handbook of Climate Change Resilience, W. L. Filho, Ed. Springer International Publishing, 2018.

62. Di Falco S, Veronesi M, Yesuf M. Does adaptation to climate change provide food security? A micro-perspective from Ethiopia. Am J Agr Econ. 2011;93(3):825-42.

63. Hailemariam T, Mekonnen A, Di Falco S, Kohlin G. Does adoption of multiple climate-smart practices improve farmers 'climate resilience? 
empirical evidence from the nile basin of ethiopia. Clim Change Econ 2017:8(01):1750001.

64. Chandio AA, Yuanshend J." "Determinants of Adoption of Improved Rice Varieties in", Rice Science. China Nat Rice Res Institute. 2018;25(August):103-10.

65. Miheretu BA, Yimer AA. Determinants of farmers' adoption of land management practices in Gelana sub-watershed of Northern highlands of Ethiopia. Ecol Process. 2017;6(1):19.

66. Swindale A, Bilinsky P. Household Dietary Diversity Score (HDDS) for Measurement of Household Food Access : Indicator Guide (V2). Washington, D.C.: Food and Nutrition Assitsance II Project (FANTA); 2006.

67. Nyamangara J, Mugwira LM, Mpofu S. Soil fertility status in the communal areas of zimbabwe in relation to sustainable crop production soil fertility status in the communal areas of Zimbabwe in Relation to Sustainable Crop Production. J Sustain Agricu. 2000;16(November):15-29.

68. Nyamangara J, Masvaya EN, Tirivavi R, Nyengerai K. Effect of hand-hoe based conservation agriculture on soil fertility and maize yield in selected smallholder areas in Zimbabwe. Soil Tillage Res. 2013;126:19-25.

69. ZimStat, Zimbabwe Smallholder Agricultural Productivity Survey 2017 Report. 2019.

70. ZimVAC. Zimbabwe Vulnerability Assessment Committee. Harare, Zimbabwe. 2019.
71. Moroda GT, Tolossa D, Semie N. Food insecurity of rural households in Boset district of Ethiopia: a suite of indicators analysis. Agric Food Secur. 2018;7:1-16.

72. Mango N, Zamasiya B, Makate C, Nyikahadzoi K, Siziba S. Factors influencing household food security among smallholder farmers in the Mudzi district of Zimbabwe. Devel Southern Afr. 2014;31 (January 20154):37-41.

73. Nwokolo EE. The influence of educational level on sources of income and household food security in alice, Eastern Cape, South Africa. J Hum Ecol. 2017;52(3):208-17.

74. Mota AA, Lachore ST, Handiso YH. Assessment of food insecurity and its determinants in the rural households in Damot Gale Woreda, Wolaita zone, sothern Ethiopia. Agric Food Secur. 2019;8(11):1-11.

\section{Publisher's Note}

Springer Nature remains neutral with regard to jurisdictional claims in published maps and institutional affiliations.
Ready to submit your research? Choose BMC and benefit from:

- fast, convenient online submission

- thorough peer review by experienced researchers in your field

- rapid publication on acceptance

- support for research data, including large and complex data types

- gold Open Access which fosters wider collaboration and increased citations

- maximum visibility for your research: over $100 \mathrm{M}$ website views per year

At BMC, research is always in progress.

Learn more biomedcentral.com/submissions 